\title{
SPK SAW PENENTUAN PAGELARAN TEATER TERBAIK
}

\author{
Dharyana Suryadijaya \\ Dosen Prodi Sistem Informasi STMIK LOGIKA MEDAN \\ dharhesya@gmail.com
}

\begin{abstract}
ABSTRAK - Penerapan Sistem Pendukung Keputusan (SPK) dapat membantu seseorang dalam mengambil keputusan yang akurat dan tepat sasaran. Banyak permasalahan yang dapat diselesaikan dengan menggunakan SPK, salah satunya adalah untuk menganalisis penentuan pagelaran teater terbaik. Metode yang dapat digunakan untuk Sistem Pendukung Keputusan ini adalah dengan menggunakan metode Simple Additive Weighting (SAW). Dalam menentukan pagelaran teater terbaik di dalam suatu festival seni pertunjukan, banyak sekali kriteria-kriteria yang harus dimiliki oleh grup teater sebagai syarat menjadi grup teater yang terbaik yang dipilih oleh dewan juri. Dewan juri memiliki kriteria-kriteria untuk menentukan siapa yang akan dipilih untuk menerima penghargaan pada malam penganugerahan grup teater yang terbaik dengan tujuan untuk mendapatkan kualitas karya seni yang bermutu dari sebuah proses latihan dari para kreator seni dan proses kreativitas seni dari seorang sutradara. Pada penelitian ini akan diangkat suatu kasus yaitu mencari alternatif terbaik berdasarkan kriteria-kriteria yang telah ditentukan oleh panitia pagelaran teater dengan menggunakan metode Simple Additive Weighting (SAW). Penelitian dilakukan dengan mencari nilai bobot untuk setiap atribut, kemudian dilakukan proses peringkat yang akan menentukan alternatif yang optimal, yaitu grup teater yang tepat mendapatkan penganugerahan teater terbaik dari sebuah festival seni pertunjukan teater.
\end{abstract}

Kata Kunci - Simple Additive Weighting, Festival Teater, Sistem Pendukung Keputusan, Pagelaran Teater Terbaik, Perangkingan.

ABSTRACT - Implementation of Decision Support Systems (DSS) can help a person to make decisions that are accurate and on target. Many problems can be solved by using the DSS, one of which is to analyze the determination of the best theater performances. The method can be used for decision support system is to use Simple Additive Weighting (SAW). In determining the best theater performances in a festival of performing arts, a lot of criteria that must be owned by the theater group as a condition of becoming the best theater groups chosen by the jury. The jury has the criteria to determine who will be selected to receive the award on the eve of the award of the best theater groups in order to get quality artwork that quality of a training process of the creators of art and the artistic creativity of a director. This research will be appointed a case of looking for the best alternative based on the criteria that have been determined by the committee theatrical performances using Simple Additive weighting method (SAW). The study was conducted by searching the weight values for each attribute, and then performed the ranking process will determine the optimal alternative, the theater group the right to get the best theatrical awarding of a performing arts festival theater.

Keyword - Simple Additive weighting, Festival Theatre, Decision Support Systems, Best Theatre performances, on Ranking.

\section{PENDAHULUAN}

Pagelaran teater merupakan suatu hal yang sangat penting bagi para pencipta seni karena menjadi puncak dari sebuah proses latihan para pencipta seni dan proses kreatifitas seni dari seorang sutradara. Untuk mengetahui tingkat keberhasilan penyutradaraan teater dilakukan penilaian terhadap kemampuan sutradara dalam menyutradarai sebuah seni pertunjukan teater, penilaian dilakukan berdasarkan kriteriakriteria penilaian. Setiap seni pertunjukan memiliki kriteria penilaian sesuai dengan jenis-jenis teater, baik dari segi bentuk dan gaya pementasan, naskah lakon, penyutradaraan, pemeranan dan tata artistik yang disajikan, kriteria-kriteria penilaian yang dibutuhkan juga berbeda, maka sebelum pagelaran teater dimulai, panitia pagelaran 
mempersiapkan daftar kriteria-kriteria penilaian yang sesuai dengan jenis teater, sehingga dewan juri dapat memberikan penilaian yang tepat.

Dikarenakan tiap-tiap dewan juri memiliki penilaian yang berbeda terhadap kriteria-kriteria penilaian, hal ini akan membuat dewan juri sulit dalam menentukan grup teater yang menyajikan pertunjukan terbaik. Penelitian ini bertujuan untuk membantu para dewan juri dalam menentukan grup teater yang menyajikan pertunjukan terbaik. Penelitian ini merupakan sebuah implementasi sistem pendukung keputusan yang didukung metode pengambilan keputusan. Metode pengambilan keputusan yang digunakan pada sistem ini metode simple additive weighting. Metode simple additive weighting bertujuan mendapatkan hasil peringkat tertinggi yang merupakan kandidat terbaik yang dapat direkomendasikan. Dengan adanya sistem pendukung keputusan yang didukung dengan metode pengambilan keputusan, maka diharapkan dapat mempercepat dewan juri dalam melakukan proses penentuan grup teater terbaik dan dapat mengurangi kesalahan dalam menentukan grup teater yang layak dipilih sebagai grup teater terbaik.

\section{KAJIAN LITERATUR}

Beberapa literature yang menerapkan sistem pendukung menggunakan metode simple additive weighting di antaranya: Afsari, Mojahed, Rosnah, Yusuff (2010) tentang Simple Additive Weighting approach to Personel selection problem. Berikutnya, Hermanto (2012) tentang sistem pendukung keputusan meggunakan metode Simple Additive Weighting (SAW) untuk menentukan jurusan pada SMK Bakti Purwokerto, kemudian Pratiwi, Lestari, Agushinta (2014) tentang Decision Support System to Majoring Hight School Student Using Simple Additive Weighting Method, kemudian Mulia (2014) tentang Sistem Pendukung Keputusan Pemberian Bonus Tahunan pada Karyawan dengan menggunakan metode Simple Additive Weighting $(S A W)$, berikutnya Widayanti, Oka, Arya (2013). Berikutnya Dodangeh, Dehafarin, Nasehifar (2012). Berikutnya Nurjoko dan Wibowo (2014) mengenai Rancang Bangun Model Seleksi Program Wirausaha Mahasiswa Berbasis Web.
Selanjutnya Goyanti L.Tobing (2014) tentang Sistem Pendukung Keputusan Pemilihan Jurusan pada Sekolah Menengah Kejuruan (SMK) Negeri 1 Siatas Barita dengan Metode Simple Additive Weighting (SAW).

\section{METODOLOGI}

Metodologi yang digunakan pada metode simple additive weighting diantaranya adalah:

1. Membuat tabel peringkat kecocokan setiap alternatif pada setiap kriteria.

2. Membuat matrix keputusan $(X)$ berdasarkan kriteria $(C j)$ yang dibentuk dari tabel penilaian kecocokan dari setiap alternatif pada setiap kriteria. Nilai $X$ setiap alternatif $(A i)$ pada setiap kriteria $(C j)$ yang sudah ditentukan, dimana $i=1,2, \ldots, m$ dan $j=1,2, \ldots, n$. Bentuk umum dari matriks keputusan $X$ pada metode simple additive weighting dituliskan pada persamaan 1 berikut:

$X=\left[\begin{array}{cccc}x_{11} & x_{12} & \ldots & x_{1 j} \\ x_{21} & x_{22} & \ldots & x_{2 j} \\ \vdots & \vdots & \vdots & \vdots \\ x_{i 1} & x_{i 2} & \ldots & x_{i j} \\ \vdots & \vdots & \vdots & \vdots \\ x_{m 1} & x_{m 2} & \ldots & x_{m n}\end{array}\right] \ldots \ldots \ldots \ldots \ldots(1)$

3. Memberikan bobot preferensi $(W)$ untuk masing-masing kriteria yang sudah ditentukan.

$$
\mathrm{W}=\left[W 1, W 2, W 3, \ldots, W_{j}\right]
$$

4. Melakukan normalisasi matriks keputusan $X$ dengan menghitung nilai peringkat kecocokan ternomalisasi $\left(r_{i j}\right)$ dari alternatif $A_{i}$ pada kriteria $C_{j}$.

$r_{i j}= \begin{cases}\frac{x_{i j}}{\operatorname{Max} x_{i j}} & \text { (benefit) } \\ \frac{\operatorname{Min} x_{i j}}{x_{i j}} & (\text { Cost })\end{cases}$

Dengan ketentuan :

a. Dikatakan atribut keuntungan (benefit) apabila atribut banyak memberikan keuntungan bagi pengambil keputusan, sedangkan 
atribut biaya (cost) merupakan atribut yang banyak memberikan pengeluaran jika nilainya semakin besar bagi pengambil keputusan.

b. Apabila berupa atribut keuntungan maka nilai $\left(\mathrm{x}_{i j}\right)$ dari setiap kolom dibagi dengan nilai $\operatorname{Max}_{i} \quad\left(\mathrm{x}_{i j}\right)$ dari tiap kolom, sedangkan untuk atribut biaya, nilai $\operatorname{Min}_{i}\left(\mathrm{x}_{i j}\right)$ dari setiap kolom atribut dibagi dengan nilai $\left(\mathrm{x}_{i j}\right)$ setiap kolom.

5. Hasil tingkat penilaian ternormalisasi $\left(r_{i j}\right)$ membentuk matriks ternomalisasi $(R)$.

$$
R=\left[\begin{array}{cccc}
x_{11} & x_{12} & \ldots & x_{1 j} \\
x_{21} & x_{22} & \ldots & x_{2 j} \\
\vdots & \vdots & \vdots & \vdots \\
x_{i 1} & x_{i 2} & \ldots & x_{i j} \\
\vdots & \vdots & \vdots & \vdots \\
x_{m 1} & x_{m 2} & \ldots & x_{m n}
\end{array}\right] \ldots \ldots(4)
$$

6. Proses perankingan dilakukan dengan cara mengalikan matriks ternormalisasi (R) dengan bobot preferensi (W).

7. Hasil akhir nilai preferensi (Vi) diperoleh dari penjumlahan perkalian elemen baris matriks ternormalisasi $(R)$ dengan bobot preferensi $(W)$.

$$
V_{i}=\sum_{j=1}^{n} W_{j} r_{i j}
$$

Nilai $V i$ yang lebih besar mengindikasikan bahwa alternatif $A i$ lebih terpilih.

\section{HASIL DAN PEMBAHASAN}

Sistem pendukung keputusan dengan metode SAW menggunakan angka yang berasal dari input data nilai kriteria hasil penjurian, kemudian nilai-nilai setiap kriteria akan digunakan untuk mendapatkan alternatif terbaik. Penentuan alternatif yang direkomendasi di dalam sistem adalah juara ke-1 (A1), juara ke-2 (A2), juara ke-3 (A3), sementara kriteria digunakan untuk menghasilkan alternatif terbaik di dalam sistem pendukung keputusan terdiri dari:

1. Pemeranan $(\mathrm{C} 1)$

2. Penyajian $(\mathrm{C} 2)$

3. Kemasan pertunjukan (C3)

4. Kedisiplinan $(\mathrm{C} 4)$

5. Penyutradaraan (C5)

6. Tata artistik (C6)

Dari masing-masing kriteria tersebut akan ditentukan bobot-bobot yang terdiri dari lima bilangan simple additive weighting yaitu, sangat rendah, rendah, menengah, tinggi dan sangat tinggi, dari masing-masing bobot tersebut dibuat suatu variabel yang akan diubah ke dalam bilangan SAW dengan rumus yaitu variabel ke-n/n-1, sebagai berikut:

\section{Variabel: 0. Sangat rendah : Bobot: Variabel ke-0/(5-1) $=0 / 4=0.00$ \\ Variabel: 1. Rendah : Bobot: Variabel ke-1/ (5-1) $=1 / 4=0.25$ \\ Variabel: 2. Menengah $\quad$ : Bobot: Variabel ke-2/ (5-1) $=2 / 4=0.50$ \\ Variabel: 3. Tinggi :Bobot: Variabel ke-3/ $(5-1)=3 / 4=0.75$ \\ Variabel: 4 . Sangat Tinggi : Bobot: Variabel ke-4/ (5-1) $=4 / 4=1.00$}

Bilangan-bilangan simple additive weighting (SAW) yang diubah tersebut disusun ke dalam tabel 4.1. sebagai berikut:

Tabel 4.1. Bobot Preferensi

\begin{tabular}{|l|c|}
\hline \multicolumn{1}{|c|}{ Nama Bobot } & Nilai Bobot \\
\hline Sangat Rendah & 0 \\
\hline Rendah & 0.25 \\
\hline Menengah & 0.5 \\
\hline Tinggi & 0.75 \\
\hline Sangat Tinggi & 1 \\
\hline
\end{tabular}


Setelah bilangan-bilangan SAW ditemukan, bilangan-bilangan tersebut digunakan sebagai bobot preferensi untuk perbandingan nilai yang diperoleh peserta setiap kriteria penilaian. Selanjutnya dibuat prioritas pembobotan kriteria yang akan digunakan untuk penentuan prioritas kriteria yang lebih diutamakan dalam perhitungan vektor bobot yang akan disajikan pada tabel 4.2, sebagai berikut:

Tabel 4.2. Prioritas Pembobotan Kriteria

\begin{tabular}{|l|l|c|}
\hline \multicolumn{1}{|c|}{ Kriteria } & \multicolumn{1}{c|}{ Bobot } & Nilai Bobot \\
\hline Pemeranan & Sangat Tinggi & 1.00 \\
\hline Penyutradaraan & Tinggi & 0.75 \\
\hline Tata Panggung & Tengah & 0.50 \\
\hline Tata Musik & Rendah & 0.25 \\
\hline Tata Cahaya & Rendah & 0.25 \\
\hline Tata Busana & Tengah & 0.50 \\
\hline Tata Rias & Tinggi & 0.75 \\
\hline
\end{tabular}

Pada masing-masing kriteria pada tabel 4.2, ditentukan rentang nilai kriteria untuk peringkat kesesuaian nilai dalam mengolah nilai penjurian pada tahap tingkat kecocokan nilai (suitability rating) pada tabel 4.3 , sebagai berikut:

\section{Tabel 4.3. Penjabaran Rentang Nilai Kriteria dan Bobot}

\begin{tabular}{|c|c|c|c|c|c|}
\hline \multicolumn{4}{|c|}{ Rentang Nilai } & Nama Bobot & Nilai Bobot \\
\hline Nilai $>=$ & 0 & Nilai $<=$ & 140 & Sangat Rendah & 0.00 \\
\hline Nilai $>=$ & 141 & Nilai $<=$ & 262 & Rendah & 0.25 \\
\hline Nilai $>=$ & 263 & Nilai $<=$ & 303 & Menengah & 0.50 \\
\hline Nilai $>=$ & 304 & Nilai $<=$ & 334 & Tinggi & 0.75 \\
\hline Nilai $>=$ & 335 & Nilai $<=$ & 400 & Sangat Tinggi & 1.00 \\
\hline
\end{tabular}

Pada gambar 4.1. akan disajikan diagram sistem pendukung keputusan penentuan grup penampil terbaik pada pagelaran teater, sebagai berikut
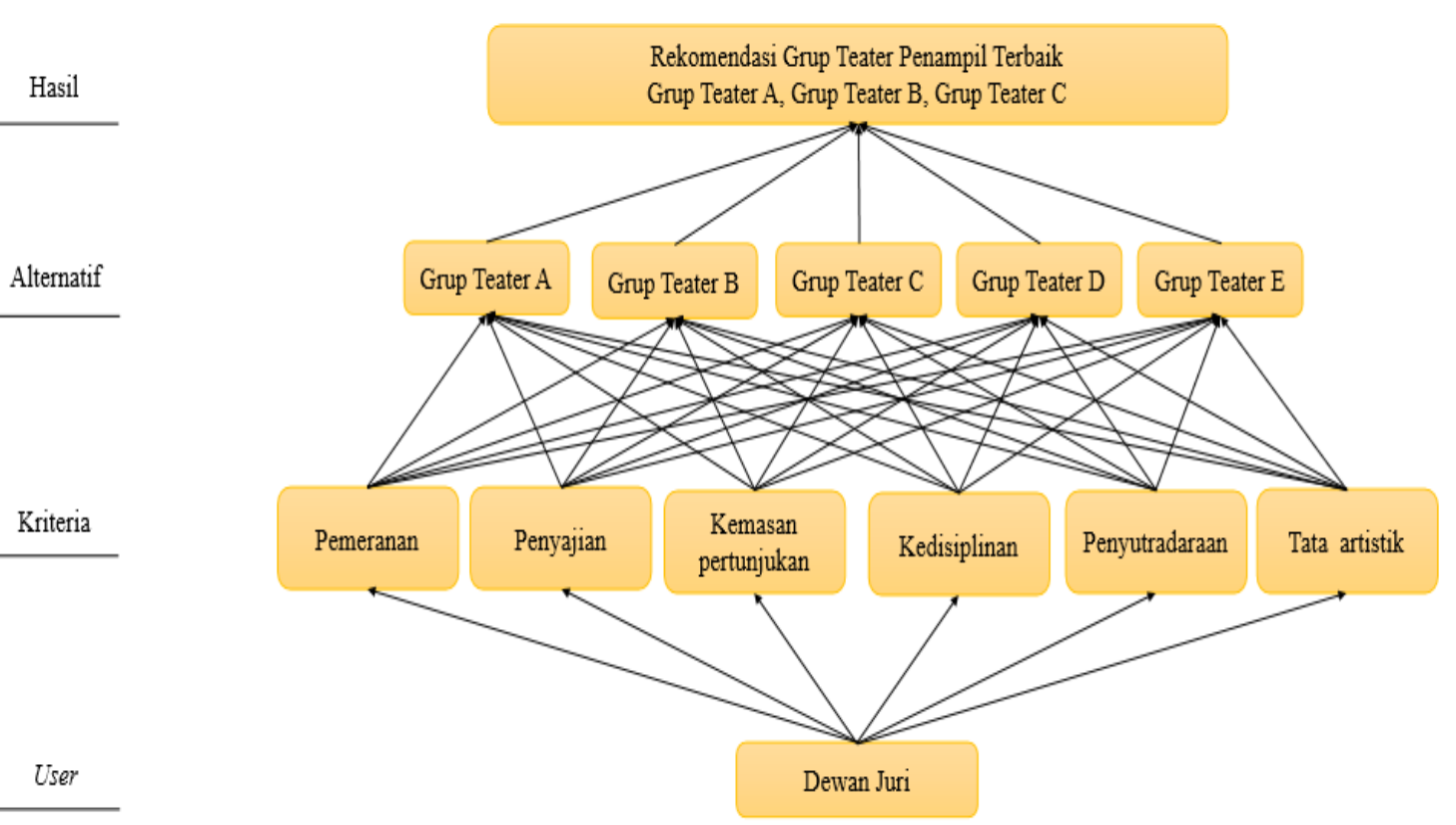

Gambar 4.1. Diagram Sistem Pendukung Keputusan Grup Teater Terbaik Pada Pagelaran Teater 
Pada tahap penilaian, nilai-nilai kriteria penilaian yang memiliki nomor grup yang sama dikelompokkan dan dijumlahkan pada tabel 4.4, contoh pengelompokan dan penjumlahan tiap kriteria per nomor undian, sebagai berikut:

Tabel 4.4 Nilai Kriteria No. Undian 1

\begin{tabular}{|l|c|c|c|c|c|c|c|c|}
\hline \multirow{2}{*}{$\begin{array}{c}\text { NAMA } \\
\text { JURI }\end{array}$} & NO & \multirow{2}{*}{$\begin{array}{c}\text { UNDIA } \\
\text { PEMER }\end{array}$} & PENYU & \multicolumn{6}{|c|}{ TANAN } & TRADA & ANARTISTIK & PANG & \multirow{2}{*}{ MUSIK } & $\begin{array}{c}\text { CAHAY } \\
\text { A }\end{array}$ & $\begin{array}{c}\text { BUSAN } \\
\text { A }\end{array}$ & RIAS \\
\hline JURI 1 & 1 & 67 & 65 & 70 & 70 & 70 & 71 & 67 \\
\hline JURI 2 & 1 & 62 & 58 & 60 & 60 & 60 & 60 & 65 \\
\hline JURI 3 & 1 & 67 & 65 & 64 & 65 & 54 & 67 & 68 \\
\hline JURI 4 & 1 & 55 & 57 & 57 & 58 & 70 & 66 & 67 \\
\hline JURI 5 & 1 & 61 & 66 & 65 & 66 & 50 & 60 & 67 \\
\hline
\end{tabular}

Sesuai dengan nama juri dan nomor undian, maka nilai-nilai per kriteria penilaian yaitu pemeranan, penyutradaraan dan untuk tata artistik yang meliputi tata panggung, tata musik, tata cahaya, tata busana, tata rias akan dijumlahkan, begitu juga untuk kriteria dari nomor undian berikutnya. Untuk contoh penjumlahan nilai-nilai kriteria dengan No. Undian 1 pada tabel 4.4, sebagai berikut:

$\begin{array}{lll}\text { PEMERANAN } & : 67+62+67+55+61=312 \\ \text { PENYUTRADARAAN } & : 65+58+65+57+66=311 \\ \text { PANGGUNG } & : 70+60+64+57+65=316 \\ \text { MUSIK } & : 70+60+65+58+66=319 \\ \text { CAHAYA } & : 70+60+54+70+50=304 \\ \text { BUSANA } & : 71+60+67+66+60=324 \\ \text { RIAS } & : 67+65+68+67+67=334\end{array}$

Setelah semua nilai kriteria per nomor undian dari nomor undian 1 sampai dengan nomor undian 23 dijumlahkan, maka nilai tersebut akan disusun ke dalam tabel seperti pada tabel 4.5, sebagai berikut: 
Tabel 4.5. Rekapitulasi Nilai Penjurian Pagelaran Teater

\begin{tabular}{|c|c|c|c|c|c|c|c|}
\hline NO & \multirow{2}{*}{$\begin{array}{c}\text { UNDIA } \\
\text { NEMER }\end{array}$} & PENYU & \multicolumn{5}{|c|}{ TATA ARTISTIK } \\
\cline { 5 - 8 } & ANAN & TRADA & PANGG & MUSIK & CAHA & BUSA & RIAS \\
\hline 1 & 312 & 311 & 316 & 319 & 304 & 324 & 334 \\
\hline 2 & 325 & 334 & 352 & 335 & 303 & 333 & 334 \\
\hline 3 & 320 & 350 & 333 & 323 & 309 & 329 & 334 \\
\hline 4 & 308 & 316 & 334 & 315 & 316 & 304 & 284 \\
\hline 5 & 369 & 351 & 351 & 332 & 334 & 357 & 353 \\
\hline 6 & 313 & 309 & 310 & 311 & 301 & 320 & 308 \\
\hline 7 & 318 & 303 & 290 & 316 & 262 & 316 & 327 \\
\hline 9 & 338 & 323 & 325 & 345 & 305 & 331 & 341 \\
\hline 10 & 380 & 371 & 369 & 335 & 326 & 339 & 349 \\
\hline 12 & 321 & 340 & 326 & 353 & 327 & 307 & 315 \\
\hline 13 & 309 & 311 & 297 & 336 & 320 & 307 & 320 \\
\hline 14 & 305 & 289 & 295 & 298 & 299 & 306 & 298 \\
\hline 15 & 342 & 333 & 337 & 325 & 317 & 301 & 320 \\
\hline 16 & 352 & 349 & 317 & 320 & 303 & 337 & 335 \\
\hline 18 & 303 & 303 & 320 & 298 & 282 & 302 & 309 \\
\hline 20 & 324 & 322 & 335 & 324 & 304 & 307 & 309 \\
\hline 21 & 337 & 348 & 336 & 324 & 303 & 336 & 349 \\
\hline 23 & 314 & 332 & 319 & 304 & 328 & 301 & 312 \\
\hline
\end{tabular}

Tahap selanjutnya menentukan tingkat kecocokan nilai setiap nilai kriteria. Perolehan setiap nilai yang telah direkapitulasi pada tabel 4.6 akan dicocokkan dan disusun ke dalam bentuk tingkat kecocokan nilai (suitability rating) dengan rentang nilai pada tabel 4.3 dan hasilnya, sebagai berikut:

Tabel 4.6. Kecocokan Nilai

\begin{tabular}{|c|r|r|r|r|r|r|r|}
\hline NO & \multirow{2}{*}{$\begin{array}{c}\text { UNDIA } \\
\text { PEMER }\end{array}$} & PENYU & \multicolumn{6}{|c|}{ TANA ARTISTI } \\
\cline { 5 - 9 } N & TRADA & PANGG & MUSIK & CAHAYA & BUSANA & RIAS \\
\hline 1 & & RAAN & UNG & & & & \\
\hline 2 & 0.75 & 0.75 & 0.75 & 0.75 & 0.75 & 0.75 & 0.75 \\
\hline 3 & 0.75 & 1.75 & 1.00 & 1.00 & 0.50 & 0.75 & 0.75 \\
\hline 4 & 0.75 & 0.75 & 0.75 & 0.75 & 0.75 & 0.75 & 0.75 \\
\hline 5 & 1.00 & 1.00 & 1.00 & 0.75 & 0.75 & 0.75 & 0.50 \\
\hline 6 & 0.75 & 0.75 & 0.75 & 0.75 & 0.75 & 1.00 & 1.00 \\
\hline 7 & 0.75 & 0.50 & 0.50 & 0.75 & 0.25 & 0.75 & 0.75 \\
\hline 9 & 1.00 & 0.75 & 0.75 & 1.00 & 0.75 & 0.75 & 0.75 \\
\hline 10 & 1.00 & 1.00 & 1.00 & 1.00 & 0.75 & 1.00 & 1.00 \\
\hline 12 & 0.75 & 1.00 & 0.75 & 1.00 & 0.75 & 0.75 & 0.75 \\
\hline 13 & 0.75 & 0.75 & 0.50 & 1.00 & 0.75 & 0.75 & 0.75 \\
\hline 14 & 0.75 & 0.50 & 0.50 & 0.50 & 0.50 & 0.75 & 0.50 \\
\hline 15 & 1.00 & 0.75 & 1.00 & 0.75 & 0.75 & 0.50 & 0.75 \\
\hline 16 & 1.00 & 1.00 & 0.75 & 0.75 & 0.50 & 1.00 & 1.00 \\
\hline 18 & 0.50 & 0.50 & 0.75 & 0.50 & 0.50 & 0.50 & 0.75 \\
\hline 20 & 0.75 & 0.75 & 1.00 & 0.75 & 0.75 & 0.75 & 0.75 \\
\hline 21 & 1.00 & 1.00 & 1.00 & 0.75 & 0.50 & 1.00 & 1.00 \\
\hline 23 & 0.75 & 0.75 & 0.75 & 0.75 & 0.75 & 0.50 & 0.75 \\
\hline
\end{tabular}


Nilai yang dihasilkan dari pengolahan data dengan cara peringkat kesesuaian atau tingkat kecocokan nilai (suitability rating) sesuai dengan nilai pada rentang nilai tabel 4.3 dan menghasilkan persentase nilai dari 0.0 sampai 1.00 , hasil nilai setiap kriteria yang telah dilakukan pencocokan nilai tersebut akan disusun ke dalam bentuk matriks keputusan $X$, sebagai berikut:

$$
x=\left(\begin{array}{lllllll}
0.75 & 0.75 & 0.75 & 0.75 & 0.75 & 0.75 & 0.75 \\
0.75 & 0.75 & 1.00 & 1.00 & 0.50 & 0.75 & 0.75 \\
0.75 & 1.00 & 0.75 & 0.75 & 0.75 & 0.75 & 0.75 \\
0.75 & 0.75 & 0.75 & 0.75 & 0.75 & 0.75 & 0.50 \\
1.00 & 1.00 & 1.00 & 0.75 & 0.75 & 1.00 & 1.00 \\
0.75 & 0.75 & 0.75 & 0.75 & 0.50 & 0.75 & 0.75 \\
0.75 & 0.50 & 0.50 & 0.75 & 0.25 & 0.75 & 0.75 \\
1.00 & 0.75 & 0.75 & 1.00 & 0.75 & 0.75 & 1.00 \\
1.00 & 1.00 & 1.00 & 1.00 & 0.75 & 1.00 & 1.00 \\
0.75 & 1.00 & 0.75 & 1.00 & 0.75 & 0.75 & 0.75 \\
0.75 & 0.75 & 0.50 & 1.00 & 0.75 & 0.75 & 0.75 \\
0.75 & 0.50 & 0.50 & 0.50 & 0.50 & 0.75 & 0.50 \\
1.00 & 0.75 & 1.00 & 0.75 & 0.75 & 0.50 & 0.75 \\
1.00 & 1.00 & 0.75 & 0.75 & 0.50 & 1.00 & 1.00 \\
0.50 & 0.50 & 0.75 & 0.50 & 0.50 & 0.50 & 0.75 \\
0.75 & 0.75 & 1.00 & 0.75 & 0.75 & 0.75 & 0.75 \\
1.00 & 1.00 & 1.00 & 0.75 & 0.50 & 1.00 & 1.00 \\
0.75 & 0.75 & 0.75 & 0.75 & 0.75 & 0.50 & 0.75
\end{array}\right)
$$

Setelah diubah ke matriks keputusan $X$, maka dilakukan perhitungan normalisasi matriks keputusan $R$, sebagai contoh dimulai dari nomor undian 1 untuk kriteria pemeranan (R11), sebagai berikut:

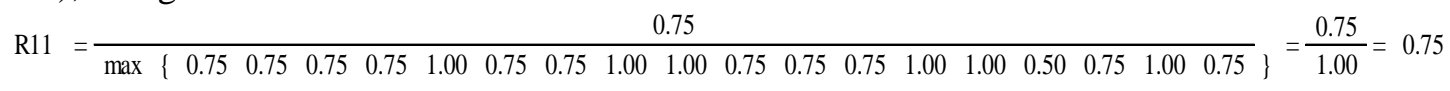

Setelah perhitungan normalisasi matriks keputusan $R$ selesai, maka hasil nilai disusun ke dalam bentuk tabel normalisasi matriks keputusan $R$, sebagai berikut: 
Tabel 4.7. Nilai Penjurian Pagelaran Teater Ternormalisasi

\begin{tabular}{|r|c|c|c|c|c|c|c|}
\hline \multirow{2}{*}{$\begin{array}{c}\text { NO } \\
\text { UNDIA } \\
\mathrm{N}\end{array}$} & \multirow{2}{*}{$\begin{array}{c}\text { PEMER } \\
\text { ANAN }\end{array}$} & $\begin{array}{c}\text { PENYU } \\
\text { RAA }\end{array}$ & \multicolumn{5}{|c|}{ TATA ARTISTIK } \\
\cline { 5 - 8 } & & PANG & MUSIK & CAHA & BUSA & RIAS \\
NA & UNA & \\
\hline 1 & 0.75 & 0.75 & 0.75 & 0.75 & 1.00 & 0.75 & 0.75 \\
\hline 2 & 0.75 & 0.75 & 1.00 & 1.00 & 0.67 & 0.75 & 0.75 \\
\hline 3 & 0.75 & 1.00 & 0.75 & 0.75 & 1.00 & 0.75 & 0.75 \\
\hline 4 & 0.75 & 0.75 & 0.75 & 0.75 & 1.00 & 0.75 & 0.50 \\
\hline 5 & 1.00 & 1.00 & 1.00 & 0.75 & 1.00 & 1.00 & 1.00 \\
\hline 6 & 0.75 & 0.75 & 0.75 & 0.75 & 0.67 & 0.75 & 0.75 \\
\hline 7 & 0.75 & 0.50 & 0.50 & 0.75 & 0.33 & 0.75 & 0.75 \\
\hline 9 & 1.00 & 0.75 & 0.75 & 1.00 & 1.00 & 0.75 & 1.00 \\
\hline 10 & 1.00 & 1.00 & 1.00 & 1.00 & 1.00 & 1.00 & 1.00 \\
\hline 12 & 0.75 & 1.00 & 0.75 & 1.00 & 1.00 & 0.75 & 0.75 \\
\hline 13 & 0.75 & 0.75 & 0.50 & 1.00 & 1.00 & 0.75 & 0.75 \\
\hline 14 & 0.75 & 0.50 & 0.50 & 0.50 & 0.67 & 0.75 & 0.50 \\
\hline 15 & 1.00 & 0.75 & 1.00 & 0.75 & 1.00 & 0.50 & 0.75 \\
\hline 16 & 1.00 & 1.00 & 0.75 & 0.75 & 0.67 & 1.00 & 1.00 \\
\hline 18 & 0.50 & 0.50 & 0.75 & 0.50 & 0.67 & 0.50 & 0.75 \\
\hline 20 & 0.75 & 0.75 & 1.00 & 0.75 & 1.00 & 0.75 & 0.75 \\
\hline 21 & 1.00 & 1.00 & 1.00 & 0.75 & 0.67 & 1.00 & 1.00 \\
\hline 23 & 0.75 & 0.75 & 0.75 & 0.75 & 1.00 & 0.50 & 0.75 \\
\hline
\end{tabular}

Nilai pada tabel 4.7. Matriks yang ternormalisasi di atas akan disusun ke dalam bentuk matriks ternoralisasi $R$ sebagai berikut:

$$
R=\left(\begin{array}{lllllll}
0.75 & 0.75 & 0.75 & 0.75 & 1.00 & 0.75 & 0.75 \\
0.75 & 0.75 & 1.00 & 1.00 & 0.67 & 0.75 & 0.75 \\
0.75 & 1.00 & 0.75 & 0.75 & 1.00 & 0.75 & 0.75 \\
0.75 & 0.75 & 0.75 & 0.75 & 1.00 & 0.75 & 0.50 \\
1.00 & 1.00 & 1.00 & 0.75 & 1.00 & 1.00 & 1.00 \\
0.75 & 0.75 & 0.75 & 0.75 & 0.67 & 0.75 & 0.75 \\
0.75 & 0.50 & 0.50 & 0.75 & 0.33 & 0.75 & 0.75 \\
1.00 & 0.75 & 0.75 & 1.00 & 1.00 & 0.75 & 1.00 \\
1.00 & 1.00 & 1.00 & 1.00 & 1.00 & 1.00 & 1.00 \\
0.75 & 1.00 & 0.75 & 1.00 & 1.00 & 0.75 & 0.75 \\
0.75 & 0.75 & 0.50 & 1.00 & 1.00 & 0.75 & 0.75 \\
0.75 & 0.50 & 0.50 & 0.50 & 0.67 & 0.75 & 0.50 \\
1.00 & 0.75 & 1.00 & 0.75 & 1.00 & 0.50 & 0.75 \\
1.00 & 1.00 & 0.75 & 0.75 & 0.67 & 1.00 & 1.00 \\
0.50 & 0.50 & 0.75 & 0.50 & 0.67 & 0.50 & 0.75 \\
0.75 & 0.75 & 1.00 & 0.75 & 1.00 & 0.75 & 0.75 \\
1.00 & 1.00 & 1.00 & 0.75 & 0.67 & 1.00 & 1.00 \\
0.75 & 0.75 & 0.75 & 0.75 & 1.00 & 0.50 & 0.75
\end{array}\right)
$$


Setelah matriks keputusan ternormalisasi $R$ dibentuk, akan dibuat perkalian vektor bobot dengan matriks ternormalisasi $R(W x R)$, dengan nilai vektor sebagai berikut:

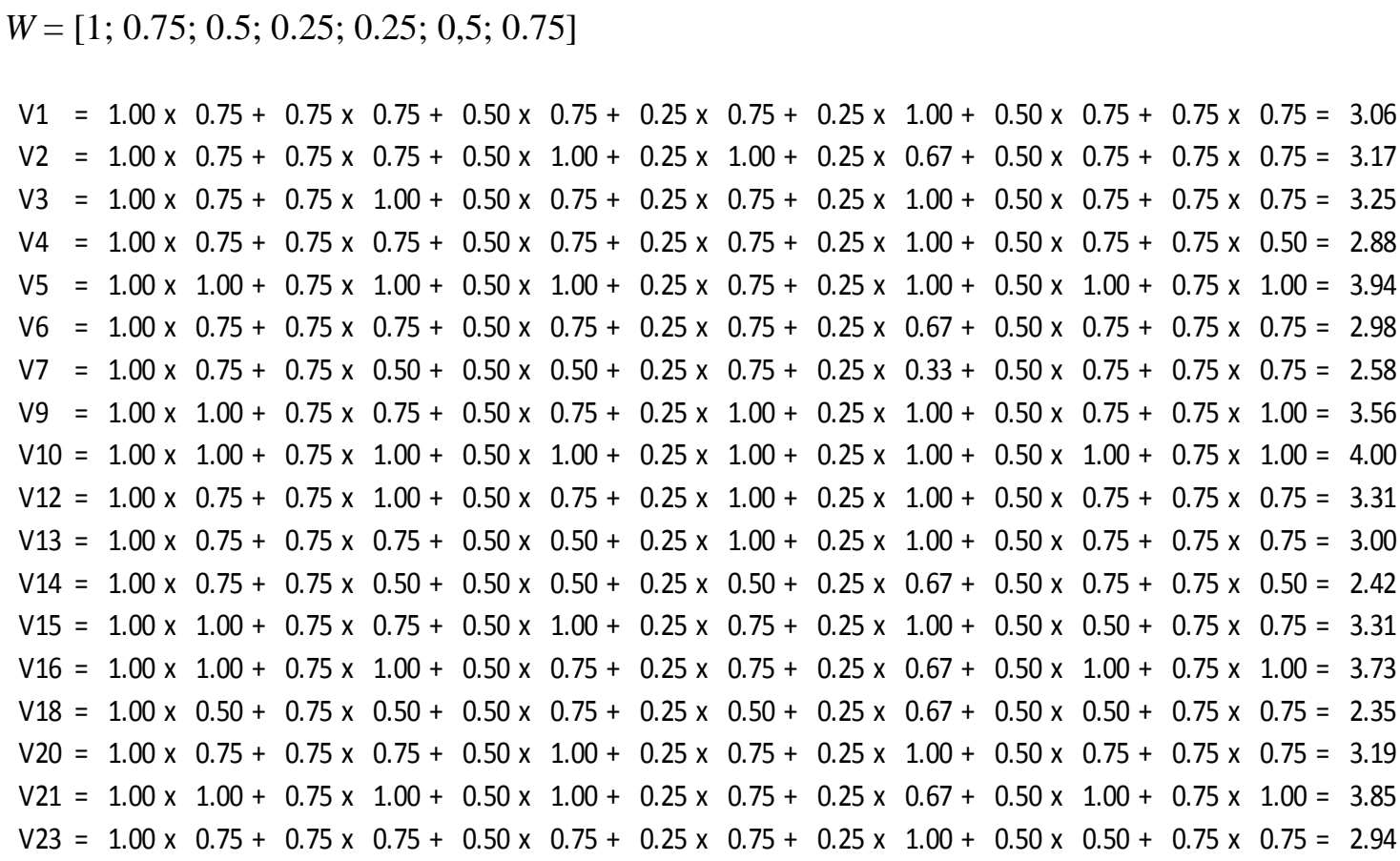

Hasil nilai dari proses perhitungan $V i$ untuk setiap kriteria dan bobot akan disusun dan disajikan pada tabel 4.8 yang menyajikan perbedaan hasil perolehan nilai setiap grup, hasil perolehan nilai yang tertinggi akan diurutkan dari nilai yang terbesar ke nilai yang terkecil, sebagai berikut:

Tabel 4.8. Rekapitulasi Informasi Peringkat Nilai Pagelaran Terbaik

\begin{tabular}{|c|l|c|c|}
\hline $\begin{array}{c}\text { No } \\
\text { Undian }\end{array}$ & \multicolumn{1}{|c|}{ Asal Daerah } & Hasil & Rangking \\
\hline 10 & Kab. Aceh Besar & 4.00 & 1 \\
\hline 5 & Kab. Aceh Tenggara & 3.94 & 2 \\
\hline 21 & Kab. Aceh Tamiang & 3.85 & 3 \\
\hline 16 & Kab. Aceh Utara & 3.73 & 4 \\
\hline 9 & Kota Sabang & 3.56 & 5 \\
\hline 12 & Kab. Nagan Raya & 3.31 & 6 \\
\hline 15 & Kota Banda Aceh & 3.31 & 7 \\
\hline 3 & Kab. Aceh Barat & 3.25 & 8 \\
\hline 20 & Kab. Bireun & 3.19 & 9 \\
\hline 2 & Kab. ABDYA & 3.17 & 10 \\
\hline 1 & Kab. Aceh Timur & 3.06 & 11 \\
\hline 13 & Kab. Pidie Jaya & 3.00 & 12 \\
\hline 6 & Kab. Pidie & 2.98 & 13 \\
\hline 23 & Kota Langsa & 2.94 & 14 \\
\hline 4 & Kota Lhokseumawe & 2.88 & 15 \\
\hline 7 & Kab. Simeuleu & 2.58 & 16 \\
\hline 14 & Kab. Subbulussalam & 2.42 & 17 \\
\hline 18 & Kab. Aceh Singkil & 2.35 & 18 \\
\hline
\end{tabular}


Seperti yang disajikan di dalam tabel 4.8, grup teater yang direkomendasikan untuk juara ke-1 dengan nilai tertinggi adalah nomor undian 10 dengan nilai 4.00 , juara ke-2 adalah nomor undian 5 dengan nilai 3.94 dan juara ke-3 adalah grup dengan nomor undian 21 dengan nilai 3.85 , juara ke-4 dengan nilai tertinggi adalah nomor undian 16 dengan nilai 3.73 , juara ke-5 dengan nilai tertinggi adalah nomor undian 9 dengan nilai 3.56.

\section{KESIMPULAN DAN SARAN}

Kesimpulan

Berdasarkan uraian dari tahapan yang sudah dibahas sebelumnya dapat ditarik kesimpulan sebagai berikut:

a. Sistem pendukung keputusan ini dapat membantu proses menentukan grup teater terbaik yang akan dipilih sebagai pagelaran teater terbaik berdasarkan penjumlahan terbobot dari prioritas kriteria-kriteria yang telah ditentukan oleh panitia pagelaran teater sebelumnya. Perhitungan nilai bobot yang berbeda dari setiap kriterianya akan menghasilkan nilai yang berbeda dan menghasilkan keputusan yang berbeda, karena penilaian para juri pagelaran teater terhadap seni pertunjukan yang disajikan oleh grup teater memiliki sentuhan tersendiri di dalam penilaian dan hal ini menyebakan perbedaan pada penilaian per kriterianya.

\section{Saran}

Berdasarkan hasil dari penelitian, ada beberapa saran yang sebaiknya dilakukan untuk pengembangan sistem yang lebih baik, diantaranya sebagai berikut :

a. Sistem yang dirancang merupakan sistem pendukung keputusan penentuan pagelaran teater terbaik, untuk pengembangan sistem dengan ruang lingkup festival seni pertunjukan teater dapat dilakukan dengan merancang sistem, sebagai berikut:
a. Pimpinan Produksi Terbaik
b. Manajemen Produksi Terbaik
c. Sutradara Terbaik
d. Aktor Terbaik
e. Aktris Terbaik
f. Setting / Dekorasi Panggung Terbaik
g. Penata Kostum Terbaik
h. Penata Make Up / Rias Terbaik
i. Penata Lampu / Lighting Terbaik

j. Penata Musik / Ilustrasi Musik Terbaik

k. Penyeleksian Kelompok Teater atau audisi yang berhasil ikut pagelaran

b. Diharapkan kedepannya sistem ini dapat dirancang dalam bentuk web dan membangun sistem yang lebih userfriendly sehingga dapat menigkatkan kinerja sistem dimasa yang akan datang.

c. Diharapkan kedepannya sistem pendukung keputusan ini dapat diterapkan dengan berbagai metode yang ada agar hasil keputusannya menjadi lebih akurat.

\section{DAFTAR PUSTAKA}

[1] ALIREZA AFSHARI, M. M. A. R. M. Y. (2010). Simple Additive Weighting approach to Personnel Selection problem. International Journal of Innovation, Management and Technology, Vol. 1, No. 5, December 2010.

[2] ALTER, S. (2013). Work System Theory: Overview of Core Concepts, Extensions, and Challenges for the Future. Journal of the Association for Information System.

[3] DYAH PRATIWI1, J. P. L., DEWI AGUSHINTA R.3 (2014). Decision Support System to Majoring High School Student Using Simple Additive Weighting Method. International Journal of Computer Trends and Technology (IJCTT), volume 10 number 3.

[4] EKO SANTOSO, D. (2008). Seni Teater untuk Sekolah Menengah Kejuruan.

[5] HERMANTO, N. (2012). SISTEM PENDUKUNG KEPUTUSAN MENGGUNAKAN METODE SIMPLE ADDITIVE WEIGHTING (SAW) UNTUK MENENTUKAN JURUSAN PADA SMK BAKTI PURWOKERTO. Seminar Nasional Teknologi Informasi \& Komunikasi Terapan 2012 (Semantik 2012) Semarang, 23 Juni 2012.

[6] L.TOBING, G. (2014). SISTEM PENDUKUNG KEPUTUSAN PEMILIHAN JURUSAN PADA SEKOLAH MENENGAH KEJURUAN (SMK) NEGERI 1 
SIATAS BARITA DENGAN METODE SIMPLE ADDITIVE WEIGHTING (SAW). Majalah Ilmiah Informasi dan Teknologi Ilmiah (INTI), Volume : IV, Nomor : 3 , Oktober 2014.

[7] MULIA, N. G. (2014). SISTEM PENDUKUNG KEPUTUSAN PEMBERIAN BONUS TAHUNAN PADA KARYAWAN DENGAN MENGGUNAKAN METODE SIMPLE ADDITIVE WEIGHTING (SAW). Pelita Informatika Budi Darma, Volume : VII, Nomor: 3, Agustus 2014.

[8] NURJOKO, H. W. (2014). RANCANG BANGUN MODEL SELEKSI PROGRAM WIRAUSAHA MAHASISWA BERBASIS WEB. Proseding Seminar Bisnis \& Teknologi, SEMBISTEK 2014 IBI DARMAJAYA, Lembaga Pengembangan Pembelajaran, Penelitian \& Pengabdian Kepada Masyarakat.

[9] PRAYOKO, M. R. (2013). SISTEM PENDUKUNG KEPUTUSAN PENENTUAN JURUSAN PADA SEKOLAH MENENGAH ATAS SMA SETIA BUDI ABADI PERBAUNGAN DENGAN MENGGUNAKAN METODE SIMPLE ADDITIVE WEIGHTING (SAW). Pelita Informatika Budi Darma, Volume : V, Nomor: 2, Desember 2013.

[10] WIDAYANTI-DENI1, O.-S. A. A.-S. 2013. Analysis and Implementation Fuzzy Multi-Attribute Decision Making SAW Method for Selection of High Achieving Students in Faculty Level. IJCSI International Journal of Computer Science Issues, Vol. 10, Issue 1, No 2. 